\title{
Improving Motor Skills of Tribal Children of Anak Dalam Sakai in Riau Province from Perspectives of Nutritional Status, Play Activities, and Physical Fitness
}

\author{
Gusril \\ Faculty of Sports Sciences, Universitas Negeri Padang Padang, Indonesia \\ Corresponding author.Email: nasir_gusril@yahoo.com
}

\begin{abstract}
This study aims to improve the motor skills of tribal children of Suku Dalam in Sakai, Riau Province through: (1) improving nutritional status, including reintegrating nutrition into the elementary school curriculum as an effort to develop healthy living lifestyle that is inseparable from healthy diet (regular, healthy and nutritious), nutrition counseling, nutritional assistance services for tribes of Anak Dalam Sakai through Integrated Healthcare Center (Posyandu), Community Health Center (Puskesmas), Family Health Programs, periodic nutritional status checks; (2) increasing play activities, including applying sports modification into PE course, adopting children's tribal play activities into PE course, (3) increasing physical fitness through particular games that stimulate the heart and lungs. $\mathrm{PE}$ teachers increase learning activities, intensity, frequency, duration and motivation to exercise.
\end{abstract}

\section{Keywords: Motor Skills, Nutritional Status, Play Activities, Physical Fitness}

\section{INTRODUCTION}

Physical and Health Education (PHE) is a part of overall education that prioritizes physical activities and fostering healthy lifestyles, growth, and development that are harmonious, harmonious, and balanced. PHE must be process-oriented to achieve success in the development of children into whole human beings ( Mutohir, 2017). In a sense, the learning process is oriented towards high learning activities and a sense of pleasure. If the learning activities are high and there is already a sense of pleasure in doing PHE, elementary school students will make the most of their learning time with activities of movement and joy. Students will experience various kinds of movements, and it will raise students' motivation to do PHE activities. The purpose of PHE in elementary schools is to assist students in developing and enhancing knowledge, skills, and attitudes as well as physical fitness, which prioritize physical activities and fostering healthy lifestyles. If the goals and functions of the PHE have been achieved, the knowledge, skills, attitudes, physical fitness, and students' motor skills will get better because they experience various movements. Motor skill is a person's ability related to the implementation of the demonstration of a skill that is relatively inherent after childhood (Gusril, 2017).

Raja (2019) states that the motor skills of children in the Riau Province are in a sufficient category. In a sense, as a whole, the motor ability of the tribal in children is not yet mature when viewed from its growth and development. It may be due to the monotony of PHE learning that is more teacheroriented. Mutohir claims that teacher-oriented learning in PHE as traditional learning. Furthermore, regular PHE teachers tend to use sports approaches in the learning process. As a result, students certainly do not feel happy and frustrated when they do PHE. The impact of all the phenomena that exist in PHE affects elementary school students, among others: low motor skills, and lack of motivation of tribal elementary school students in participating in PHE learning. Based on the problems proposed above, there are several factors influence this issue, comprising nutritional status, play activities, and physical fitness.

Nutritional status is a condition of each individual that is influenced by the use of food substances (Gusril, 2017). The food substances that are consumed are useful for growth and development, as well as providing calories for students in doing physical activities. If the nutritional status of students is good, it will affect students' movement to carry out daily activities well. Conversely, students who have excess nutrition (obesity) or less, they will experience negative impacts on their movements. Generally, students who have excess or lack of nutrition tend to be lazy so that their motor skills will be affected.

Playing is one of the fun activities carried out for the sake of the play itself (Santrock, 2012: 306). Santrock explains that the term "play" itself is to describe the activity carried out for pleasure. Thus, the 
activity of playing involves physical activity although a little.

Gusril (2016, 147) explains that physical fitness is aspects of physical ability that support one's success in carrying out various activities in his life. Furthermore, the higher the level of physical fitness of a person, the more likely it is to complete a job and the higher the opportunity to enjoy life. So, it can be concluded that a person's physical fitness can affect one's ability to carry out activities.

\section{RESEARCH METHODS}

It was quantitative research using Path analysis techniques. The population is the tribal children of Anak Dalam in Sakai, amounting to 89 students. The research sample was drawn using a purposive sampling technique and obtained a sample of 30 students. The research instruments used were the motor ability test of Scoot's test modified by Gusril (2017), nutritional status using weight scales and measuring height, play activity using the Gusril's instrument (2017), and physical fitness using the Harvard Step Test. Data were analyzed using Path Analysis .

\section{RESEARCH RESULTS AND DISCUSSION}

A It was found that there was a direct effect of nutritional status (X1) on motor skills (Y) ( $\mathrm{yyx} 1)=$ 0.407. It was obtained that tobserved was higher than the ttable, 2.552> 1.701. Then, Ha was accepted, and H0 was rejected which implied a significant path analysis coefficient.

Thus, there was a direct effect on the nutritional status of the motor skills of Anak Dalam Sakai tribal children in Riau Province. The finding was following theoretical studies, theoretical frameworks, and hypotheses proposed so that this study can be accepted empirically.

This finding was supported by similar research conducted by Astyorini (2014) which found a significant effect on the moderate category of nutritional status on gross motor skills of elementary school children. At school age, physical and social growth occurs rapidly, so, at this age, children need more nutrition to support the growth and development of physical activities, especially the development of motor skills.

The relationship of nutritional status is inseparable from diet patterns. Most of the students at school consume snacks in the canteen, which contain a lot of MSG and preservatives, coloring, and other packaged foods. Meanwhile, fulfilling the nutritional needs at home, which is the responsibility of parents or guardians of children, becomes an obstacle when they are lack of knowledge about the importance of nutrition issues for children's growth and development. Mandal et al. (2014) found issues of immunization coverage in Kolkata, India. Furthermore, special attention must be given to improve nutrition education for mothers.

Besides, another thing that is also a set of interrelated factors is socioeconomic status. The research conducted in India by Kanjilal (2010) showed that socioeconomic status was the factor that most influences the state of malnutrition there. The nutritional status and motor skills of elementary school students should be considered. Fulfilling the needs of proper nutrition can support the motor skills of students that will affect their future lives. It will affect not only the cognitive domain but also the psychomotor domain.

Efforts that can be made to improve the nutritional status of the motor abilities of Anak Dalam Sakai tribes by reintegrating nutrition into the elementary school curriculum as an effort to develop healthy lifestyle that is inseparable from healthy diet (regular, healthy and nutritious), nutrition counseling, nutritional assistance services through Integrated Healthcare Center (Posyandu), Community Health Center (Puskesmas), Family Health Programs, periodic nutritional status checks;

2. It was found that there was a direct effect of play activities $(\mathrm{X} 2)$ on motor skills $(\mathrm{Y})(\rho \mathrm{YX} 2=0.412)$. It was obtained that tobserved was higher than the ttable, 2.453> 1.701. Then, Ha was accepted, and H0 was rejected, which implied a significant path analysis coefficient.

Thus, there was a direct effect on play activities on the motor skills of Anak Dalam Sakai tribal children. The finding was following theoretical studies, theoretical frameworks, and hypotheses proposed so that this study can be accepted empirically.

The finding was supported by the theory proposed by Saputra and Fantiro (2017) explaining that viewed from the activities of students in primary schools; they can be considered carefully, in fact, students in primary schools have daily activities while resting at school was always filled with activities of physical activity. Students in elementary school move with their motor skills, speed, agility and strength that they have themselves. When playing, they can run around even faster when playing chases with friends or chasing the ball. They can also do activities for a long time without feeling tired, sometimes even doing more than one game. 
In line with Fadilah and Wibowo (2017), game activities consist of a variety of mobility and play abilities that students must master to gain success in a game. Likewise, Pellegrini in Ericsson (2016) find that sports games (with gross motor movements) increase and reach a peak during elementary school. However, basic motor skills can be an essential factor in motivation to be physically active and able to participate in physical and social play.

Mclnnes \& Birdsey explained the same thing in Tatli (2018) that games prepare children physically and cognitively for life, and they are tools that enhance their creativity, develop their problem-solving skills and enhance their feelings of freedom. There is great potential for using games as a learning environment.

Games are fun activities that consist of their essence, the main intrinsic motivational factors that captivate the attention of students and make them persistent and enthusiastic about these activities. Therefore the game is recognized as a valuable tool in instructional design that strives to create an exciting and educative learning environment (Stojanovska et al., 2014). According to Sujiono (2013), learning through play can develop various potentials in children, not only physical or motoric but also cognitive, language, social, emotional, creativity and ultimately academic achievement. If previously playing was said to be a practical education without being planned, in learning physical education, play activities also become an essential part because it is a movement activity that trains and supports the development of motor skills. Efforts can be made to increase play activities on the motor skills of Anak Dalam tribal children in a way specifically for PHE learning. The teacher should apply sports modifications into PHE, adopting play activities of the Anak Dalam tribe into the PHE course.

3. It was found that there was a direct effect of physical fitness (X3) on motor skills, (Y) $\rho \mathrm{YX} 3=$ 0.309. It was obtained that tobserved was higher than ttable, 1.843> 1.701. Then, Ha was accepted, and H0 was rejected, which implied a significant path analysis coefficient.

Thus, there was a direct effect of physical fitness on the motor ability of the Anak Dalam tribes. The impact of physical fitness on the motor ability of the Anak Dalam tribes was $11.56 \%$, while other factors influenced the remaining $88.44 \%$. The finding is following theoretical studies, theoretical frameworks and hypotheses proposed so that this study can be accepted empirically.

The finding was supported by the theory proposed by Wijayanto and Muhammad (2014); physical fitness had a function to develop strength, skills, power, and endurance. It means by having good physical fitness, students can practice their motor skills with planned or unplanned physical activity.

Sukamti et al. (2016) explain that physical fitness can be affected by age, gender, heredity, food, smoking habits, and exercise. In the case of food, diet patterns that are applied will affect a person's nutritional status, thereby affecting one's physical fitness.

Efforts that can be made to improve physical fitness for the motor skills of the Anak Dalam Sakai by increasing physical fitness through particular games that stimulate the heart and lungs. PHE teachers increase learning activities, intensity, frequency, duration and motivation to exercise.

4. It was found that there was an indirect effect of Nutrition Status (X1) through physical fitness (X3) on motor skills $(\mathrm{Y}), \rho \times 31=0.283$, $\rho \mathrm{yx} 3=0.309$. It was obtained that tobserved was greater than the ttable, 1.805> 1.701. Then, Ha was accepted and $\mathrm{H} 0$ was rejected, which implied a significant path analysis coefficient.

Thus, nutritional status had an indirect effect on motor ability through physical fitness. The finding is following theoretical studies, theoretical frameworks and hypotheses proposed so that this study can be accepted empirically.

Rahmawati (2016) states that children at primary school age have more activities, both at school and outside of school, so children need more energy. Meanwhile, physical fitness is the condition of a person's body that can carry out daily activities without feeling tired or stressed and can even do other things outside of daily activities.

It is in line with what was stated by Sukamti et al. (2016) that physical fitness can be affected by age, gender, heredity, food, smoking habits, and exercise. In the case of food, consumption patterns that are applied will affect a person's nutritional status, thereby affecting one's physical fitness.

Excellent motor skills can not be obtained just like that; there are supporting factors. Physical fitness is very closely related to developing motor skills. Physical fitness is also obtained from proper nutrition. That is, there is an indirect effect given the nutritional status of motor ability through physical fitness. Students with functional nutritional status have functional physical fitness, which can then have excellent motor skills.

5. It was found that there was an indirect effect of play activity (X2) through physical fitness (X3) on motor ability (Y), $\rho x 32=0.508$, $\rho y x 3=0.309$. It was obtained that tobserved was higher than ttable, 3,236> 1,701. Then, Ha was accepted and $\mathrm{H} 0$ was rejected, which implied a significant path analysis coefficient.

Thus, play activities was indirectly affected motor skills through physical fitness. The finding is 
following theoretical studies, theoretical frameworks and hypotheses proposed so that this study can be accepted empirically.

Besides nutritional status, physical fitness is also affected by play activities. Physical fitness based on research data is mostly in the good and poor categories. However, this cannot be separated from the effect of Anak Dalam Sakai tribal children's play activities. Moreover, the play activities of Anak Dalam Sakai tribal children are not done only in schools but also outside of school time.

Play activity affects the physical fitness of Anak Dalam Sakai tribal children; the more play activities are carried out, the more physical fitness the child has to carry out. However, play activities carried out are physical activities or movements as a whole, which indirectly affect motor skills through physical fitness.

The finding is supported by the theory proposed by Chen et al. (2015), explained that cross-sectional studies had found a positive relationship between basic motor skills competency and physical activity in children. Likewise, Stodden et al. in Chen et al. (2015) also found a reciprocal relationship and dynamic development between motor skills competency and physical activity.

Table 1. Summary of Model Suitability Test Results

\begin{tabular}{|c|c|c|c|c|c|}
\hline $\begin{array}{c}\text { Effect } \\
\text { between }\end{array}$ & 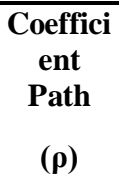 & $\begin{array}{c}\mathbf{T}_{\text {observ }} \\
\text { ed }\end{array}$ & $\begin{array}{c}\text { P- } \\
\text { Value }\end{array}$ & $\begin{array}{c}\mathbf{T} \\
\text { table }\end{array}$ & $\begin{array}{l}\text { Concl } \\
\text { usion }\end{array}$ \\
\hline $\mathrm{X} 1$ to $\mathrm{Y}$ & 0,407 & 2,552 & 0,017 & \multirow{5}{*}{$\begin{array}{c}1,70 \\
1\end{array}$} & Sig. \\
\hline $\mathrm{X} 2$ to $\mathrm{Y}$ & 0,412 & 2,453 & 0,021 & & Sig. \\
\hline $\mathrm{X} 3$ to $\mathrm{Y}$ & 0,309 & 1,843 & 0,077 & & Sig. \\
\hline $\mathrm{X} 1$ to $\mathrm{X} 3$ & 0,285 & 1,805 & 0,082 & & Sig. \\
\hline $\mathrm{X} 2$ to $\mathrm{X} 3$ & 0,506 & 3,108 & 0,004 & & Sig. \\
\hline
\end{tabular}

\section{B. Conclusions}

Based on data analysis and discussion, the following conclusions can be made: Increasing the motor skills of the Anak Dalam Sakai tribal children through:

1. Improvement of nutritional status, consisting of reintegrating nutrition into the elementary school curriculum as an effort to develop healthy lifestyle that is inseparable from healthy diet (regular, healthy and nutritious), nutrition counseling, nutritional assistance services through Integrated
Healthcare Center (Posyandu), Community Health Center (Puskesmas), Family Health Programs, periodic nutritional status checks;

2. Increased play activities: apply sports modifications into PHE, adopting play activities of the Anak Dalam tribe into the PHE course.

3. Increased physical fitness through particular games that stimulate the heart and lungs. PHE teachers increase learning activities, intensity, frequency, duration and motivation to exercise.

\section{REFERENCES}

[1] Alpyan, Raja T. 2018. The Existence of Traditional Games in Meeting the Need of Motoric Development Paticipating. Proceeding The 3rd International Conference on Education-Teachers in The Digital Age. Batu Sangkar: Fakultas Tarbiyah dan Ilmu Keguruan IAIN Batusangkar.

[2] Alamsyah, Nurul, DA. (2017). Faktor-Faktor Yang Berhubungan Dengan Kebugaran Jasmani Pada Remaja Siswa Kelas Xi Smk Negeri 11 Semarang. Jurnal Kesehatan Masyarakat (E-Journal) Volume 5, Nomor 3, Juli 2017 (ISSN: 2356-3346). Hal 7786.

[3] Bryantara, OF. (2016). Faktor Yang Berhubungan Dengan Kebugaran Jasmani (Vo2 Maks) Atlet Sepakbola. Jurnal Berkala Epidemiologi, Vol. 4 No. 2, Mei 2016: 237-249.

[4] Gusril. (2016). Perkembangan Motorik Pada Masa Anak-Anak. Padang: UNP PRESS.

[5] Hasanah, Uswatun. (2016). Pengembangan Kemampuan Fisik Motorik Melalui Permainan Tradisional Bagi Anak Usia Dini. Jurnal Pendidikan Anak, Volume 5, Edisi 1, Juni 2016. Hal. 717-733.

[6] Khairuddin. (2016). Penerapan Ilmu Gizi Dalam Aktivitas Olahraga. Padang: Suka Bina Press.

[7] Saputra, Yunus S \& Fantiro, FA. 2017. Permainan Motorik Untuk Sekolah Dasar. Prosiding SENASGABUD report.umm.ac.id/index.php/ SENASGABUD (Seminar Nasional Lembaga Kebudayaan) Edisi 1 Tahun 2017, Hal. 149-155.

[8] Sa'adah, dkk. 2014. Hubungan Status Gizi dengan Prestasi Belajar Siswa Sekolah Dasar Negeri 01 Guguk Malintang Kota Padangpanjang. Jurnal Kesehatan Andalas. 2014; 3(3) http://jurnal.fk.unand.ac.id, Hal. 460-465.

[9] Stojanovska TV. et al. 2014. The Educational Prospects of Traditional Games as Learning Activities of Modern Students. https://www.researchgate.net/publication/ 272127194 Conference Paper . October 2014. 
[10] Sugiyono. 2010. Metode Penelitian Pendidikan (Pendekatan Kuantitatif, Kualitatif, dan R \& D). Bandung: Afabeta.

[11] Sukamti, ER., dkk. (2016). Profil Kebugaran Jasmani Dan Status Kesehatan Instruktur Senam Aerobik Di Yogyakarta. Jurnal Olahraga Prestasi, Volume 12, Nomor 2, Juli 2016 Hal. 31-40.

[12] Syahara, Sayuti. (2011). Pertumbuhan \& Perkembangan Fisik-Motorik. Padang. Fakultas Ilmu Keolahragaan Press.

[13] Wijayanto, Yuyud \& Muhammad Nur H. 2014. Hubungan Antara Tingkat Kesegaran Jasmani Dengan Keterampilan Motorik (Kelincahan) Di SMP Negeri Satu Atap Jabon (Studi pada Kelas VII). Jurnal Pendidikan Olahraga dan Kesehatan Volume 02 Nomor 02 Tahun 2014, http://ejournal.unesa.ac.id/index.php/jurnalpendidikan-jasmani/issuel archive, Hal. 345 - 349. 